\title{
PENERAPAN SISTEM INVENTORY LABOTARIUM DIGITAL DENGAN METODE CRITICAL SUCCES FACTOR PADA PERGURUAN TINGGI RAHARJA
}

\author{
Khanna Tiara ${ }^{1}$ \\ Dewi Immaniar ${ }^{2}$ \\ Fiqih Arzia ${ }^{3}$ \\ Dosen Teknik Informatika STMIK Raharja ${ }^{1}$, Dosen Teknik Informatika STMIK Raharja ${ }^{2}$, Mahasiswa \\ STMIK Raharja ${ }^{3}$ \\ email:khanna.tiara@raharja.info,dewi.immaniar@raharja.info,fiqiharzia@raharja.info
}

Diterima : 23 Januari 2015/ Disetujui : 13 Februari 2015

\begin{abstract}
The system supplies the right stuff and fit is important for College field in terms of the preparation of Perguruan Tinggi Raharja and loaning stuff on the computer systems Laboratory (Lab. Digital). Lab. Digital Perguruan Tinggi Raharja is used to perform testing, scientific research, education, practice and research. Lab. Digital is equipped with the tools needed to support the activities that are carried out so that the need for the process of recording of inventory of existing equipment in the Lab. sk. this process it is important to monitor or monitor the condition of the existing equipment. The process of recording data inventory equipment Lab. Digital still performed manually has some drawbacks, namely in terms of storage and retrieval. If the goods supplied on Lab. Digital not groomed properly then the goods will be lost and many are not well maintained, in this regard are also not recorded properly on the Lab. SK Perguruan Tinggi Raharja would suffer losses as a result of monitoring the preparation did not go well. This has been the rationale of how making an inventory system so ease Perguruan Tinggi Raharja for monitoring data collection, monitoring of loan items of goods and the creation of reports in the Lab. Digital it is possible to use a combination of using the method of analysis of CSF (Critical Success Factor) as an attempt to interpret objective explicitly to specify the activities that must be performed and what information is needed. And by making the system inventory can be seen 4 conditions of goods if the goods arelost, damaged, or expired good so that it can monitor inventory items in a Lab. Digital Perguruan Tinggi Raharja.
\end{abstract}

Keywords: Information Systems, Inventory, CSF (Critical Success Factor)

ABSTRAK

Sistem persediaan barang yang tepat dan sesuai merupakan hal penting bagi Perguruan Tinggi Raharja dalam hal bidang persedian dan peminjaman barang pada Laboratorium Sistem Komputer (Lab. Digital). Lab. Digital pada Perguruan Tinggi Raharja merupakan tempat yang digunakan untuk melakukan kegiatan pengujian, riset ilmiah, praktek pembelajaran, dan penelitian. Lab. Digital dilengkapi dengan peralatan yang dibutuhkan untuk menunjang kegiatan yang dilakukan sehingga perlu adanya proses pencatatan terhadap inventory peralatan yang ada di Lab. SK. Proses ini penting dilakukan untuk memonitor atau memantau kondisi peralatan yang ada tersebut. Proses pencatatan data inventory peralatan Lab. Digital yang masih dilakukan secara manual memiliki beberapa kekurangan yaitu dalam hal penyimpanan dan pencarian. Jika barang yang ada pada Lab. Digital tidak terawat dengan benar maka barang-barang akan hilang dan banyak yang tidak terawat, dalam hal ini juga tidak terekam dengan baik pada Lab. Digital Perguruan Tinggi Raharja yang akan mengalami kerugian akibat monitoring persedian tidak berjalan dengan baik. Hal ini menjadi dasar pemikiran bagaimana membuatkan sebuah sistem inventory sehingga memudahkan Perguruan Tinggi Raharja untuk monitoring pengumpulan data barang, monitoring peminjaman barang dan pembuatan laporan di dalam Lab. Digital. Hal ini dimungkinkan dengan menggunakan kombinasi menggunakan Metode Analisa CSF (Critical Success Factor) sebagai upaya untuk menginterpretasikan objektif 
secara lebih jelas untuk menentukan aktivitas yang harus dilakukan dan informasi apa yang dibutuhkan. Dan dengan membuatkan sistem inventory dapat di lihat 4 kondisi barang apakah barang tersebut hilang, rusak, bagus atau habis sehingga dapat memonitoring persediaan barang di Lab. Digital pada Perguruan Tinggi Raharja.

Kata kunci: Sistem informasi, Inventory, CSF (Critical Success Factor)

\section{PENDAHULUAN}

Seiring tumbuh dan berkembangnya Perguruan Tinggi Raharja dalam meningkatkan aktivitas, kemajuan ini telah mendorong mahasiswa untuk berusaha mengatasi segala permasalahan yang timbul di Perguruan Tinggi Raharja maka menuntut kemampuan dan kecakapan para pengelola dalam pengambilan keputusan dalam mengenai pengumpulan data barang pada Laboratorium Sistem Komputer (Lab. Digital) yang akan dijalankan Perguruan Tinggi Raharja, sehingga diharapkan mampu membantu mengatasi masalah yang dihadapi oleh Perguruan Tinggi Raharja.

Perguruan Tinggi Raharja membutuhkan suatu sistem yang mudah digunakan dan lebih baik untuk menyebarkan data tersebut, untuk itu dapat digunakan sebuah sistem informasi berbasis web. Web sistem informasi tersebut nantinya diharapkan dapat menjadi jalan keluar yang baik dalam hal mendata barang-barang yang keluar masuk di Lab. Digital.

Beberapa masalah dalam peminjaman barang di antaranya banyak barang rusak, hilang, bagus dan habis tidak terekam dengan baik. Memasukkan data barang-barang serta mencatat siapa sajakah yang sedang meminjam barang yang ada di Lab. Digital Perguruan Tinggi Raharja juga tidak terdata atau teknologi yang digunakan untuk mendata informasi tersebut masih bersifat manual dan sederhana. Sebagian besar barang-barang fisik mengalami kerusakan atau penurunan dari waktu ke waktu. Hal ini disebabkan karena tidak adanya peraturan internal yang menganjurkan Perguruan Tinggi Raharja untuk mencatat tanggal yang sudah di tentukan pada saat peminjaman barang dan pada saat barang masuk ke dalam Lab. Digital. Karena sulitnya mengontrol persediaan barang yang memiliki masa efektif pakai, maka digunakan kombinasi metode CSF (Critical Success Factors) dalam menentukan prioritas peminjaman barang supaya dapat menurunkan tingkat kerugian pada Perguruan Tinggi Raharja.

\section{LANDASAN TEORI}

\section{- Definisi Sistem Informasi}

Menurut Nugroho (2011:128), "Sistem informasi adalah sebuah sistem yang mempunyai fungsi mengumpulkan, memproses, menyimpan, menganalisis, dan menyebarkan informasi untuk tujuan yang spesifik".

Menurut Sutabri (2012:46), "Sistem informasi adalah suatu sistem di dalam suatu organisasi yang mempertemukan kebutuhan pengolahan transaksi harian yang mendukung fungsi operasi organisasi yang bersifat manajerial dengan kegiatan strategi dari suatu organisasi untuk dapat menyediakan kepada pihak luar tertentu dengan laporanlaporan yang diperlukan".

\section{- Definisi Critical Succes Factors}

Menurut Rockart dan Bullen 1981 MIT dalam Witarto (2004:110), CSF merupakan sejumlah variable yang mempengaruhi aktivitas yang sekarang atau yang akan datang, dalam mencapai target pekerjaannya. Metoda CSF membantu 
pendefinisian variable. Dengan demikian, manajer akan meningkatkan pemahamannya tentang situasi diruang kendalinya.

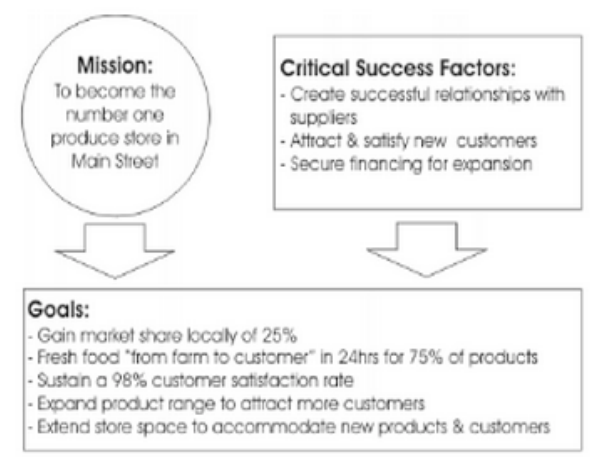

\section{Gambar 1. Critical Succes Factors}

CSFs dalam konteks perencanaan strategis sistem informasi digunakan untuk menafsirkan dengan jelas tujuan, taktik, dan kegiatan operasional dalam hal kebutuhan informasi kunci dan manajer dan kekuatan dan kelemahan dari sistem organisasi yang sudah ada.

Peranan CSFs dalam perencanaan strategis adalah sebagai penghubung antara strategi bisnis organisasi dengan strategi sistem informasi yang dimiliki, memfokuskan proses perencanaan strategis sistem informasi pada area yang strategis, memprioritaskan usulan aplikasi sistem informasi dan mengevaluasi strategi sistem informasi.

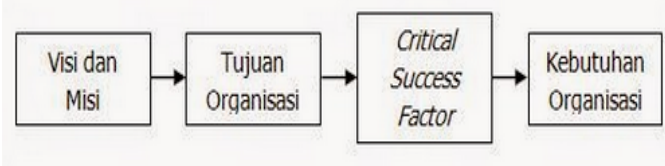

Gambar 2. Langkah-Langkah Elaborasi Tujuan Organisasi

\section{- Definisi Inventory}

Menurut Junaidi (2013:3)(2012:10), "Inventory merupakan sebuah konsep yang mencerminkan sumber daya yang dapat digunakan tetapi tidak atau belum dipergunakan". Pengertian inventory dapat diartikan dalam beberapa hal yang berbeda, yaitu stok yang tersedia pada saat itu juga, daftar perincian barang yang tersedia, atau untuk keuangan dan akunting adalah jumlah stok barang yang dimiliki oleh suatu organisasi pasa suatu waktu.

Menurut Tamodia (2013:23), "Persediaan merupakan barangbarang yang dimiliki untuk kemudiaan dijual atau digunakan dalam proses produksi atau dipakai untuk keperluan non produksi dalam siklus kegiatan yang normal".

Menurut Salangka (2013:1121), "Persediaan merupakan barangbarang yang dimiliki untuk kemudiaan dijual atau digunakan dalam proses produksi atau dipakai untuk keperluan non produksi dalam siklus kegiatan yang normal".

\section{PERMASALAHAN}

Prosedur sistem yang sedang berjalan saat ini pada proses pengumpulan data barang di dalam ruang Lab. Digital yang terdapat pada Perguruan Tinggi Raharja masih berjalan secara manual, yaitu seperti pencatatan atau pengecekan barang di dalam ruang Lab. Digital masih menggunakan kertas list barang-barang biasa sehingga data persediaan barang yang diperoleh tidak akurat dan proses yang dibutuhkan dalam pengecekan pun membutuhkan waktu yang cukup lama, dan sering terjadi kehilangan,kerusakkan, barang yang tidak balik data karena data yang punya berupa catatan yang dicatat pada kertas list barang-barang biasa.

Tidak akuratnya data dan lambatnya informasi yang diperoleh bisa menyebabkan kerugian yang cukup besar karena barang yang di pinjaman adalah barang-barang inventaris yaitu berupa kompenan dan tools atau peralatan yang mempunyai tanggal peminjaman yang beragam, sehingga sulit untuk 
dikendalikan karena pada saat barang keluar ke dalam ruang Lab. Digital tidak di catat tanggal berapa peminjaman dan hanya ditumpuk atau diurutkan saja sesuai jenisnya di dalam ruang Lab. Digital. Jika terjadi pengumpulan data yang tidak laku terdaftar itu bisa mengakibatkan kerugian bagi Perguruan Tinggi Raharja karena sulit mengetahui seberapa lama barang bisa di peminjaman dan status barang apakah masih bisa di pakai atau rusak bahkan hilang. Rumusan masalah dalam penelitian ini adalah bagaimana cara mengelola data barang yang ada di Lab. Digital pada Perguruan Tinggi Raharja, bagaimana mengontrol data peminjaman barang yang terjadi di Lab. Digital pada Perguruan Tinggi Raharja, dan bagaimana menciptakan suatu sistem yang mampu membantu Perguruan Tinggi Raharja dalam mengelola laporan data barang pada Lab. Digital. Berdasarkan rumusan masalah yang telah di identifikasi maka tujuan yang ingin dihasilkan adalah menciptakan sistem yang dapat mengelola data barang yang ada di Lab. Digital pada Perguruan Tinggi Raharja, menciptakan sebuah sistem yang mampu mengontrol data peminjaman barang yang terjadi di Lab. Digital pada Perguruan Tinggi Raharja, menciptakan suatu sistem yang mampu membantu Perguruan Tinggi Raharja dalam mengelola laporan data barang pada Lab. Digital.

\section{LITERATURE REVIEW}

1. Penelitian yang dilakukan oleh Gunardi, Dedi Sulistyo S, Taryana Suryana (2011) penelitian ini berjudul "Usulan Peta Strategi Teknologi Informasi Menggunakan Pendekatan Analisis Critical Succes Factors Dan IT Balanced Scorecard". Pada penelitian ini penulis hanya membahas mengenai Analisis Critical Succes Factor (CSF) yang dibatasi hanya pada proses prosedur pelaporan laporan keuangan belum secara cepat terselesaikan sehingga pengambilan keputusan dari pemakai laporan keuangan dalam hal ini shakeholder perusahaan sering terlambat dan bagian marketing dengan produksi masih ada ketidak cocokan perintah diakibatkan belum terintegrasinya teknologi informasi dan pemanfaatannya masih sangat sederhana di dalam PT.Sola Gratia. tersebut Analisis dilakukan dengan cara wawancara, Kuesioner dan Dokumentasi terhadap sistem yang berjalan, kebutuhan informasi sistem, dan desain menggunakan AAnalisis Critical Succes Factor (CSF) dan pembuatan program menggunakan Rancangan pembentukan Balanced Scorecard dan Rancangan Analisis CSF. Keunggulan sistem aplikasi ini terletak pada proses pengambilan keputusan dari pemakai laporan keuanganpenerimaan terdapat menu laporan keuangan yang dapat dipilih salah satunya. Untuk outputnya dalam bentuk rincian laporan perbulan, dimana bagian marketing bisa memilih bulan yang ingin dicetak pada menu cetak laporan.

2. Penelitian yang dilakukan oleh Khanna Tiara (2014) penelitian yang di lakukakan ini berjudul "Sistem Pakar Monitoring Inventory Control Untuk Menghitung Harga Jual Efektif Dalam Meningkatkan Keuntungan. Yogyakarta: Universitas Ahmad Dahlan". Pada penelitian ini penulis Sistem persediaan barang yang tepat dan sesuai merupakan hal penting bagi perusahaan dalam bidang penjualan. Jika salah dalam penanganan, dapat menyebabkan penumpukan yang berdampak pada kerugian akibat kadaluarsa, karena tidak layak jual atau kekurangan stok yang menyebabkan hilangnya pelanggan, Menciptakan Sistem Monitoring Inventory Control yang mampu membantu perusahaan dalam menjaga persediaan barang dengan 
memperhatikan masa efektif pakai sehingga barang yang dijual merupakan barang yang layak pakai dan ketersediaan barang dapat terjaga sehingga mampu membantu perusahaan dalam mengurangi tingkat kerugian yang disebabkan oleh tanggal kadaluarsa barang dan terbatasnya persediaan,dan desain menggunakan Metode FIFO (First In First Out) dalam menentukan prioritas pengeluaran barang berdasarkan tanggal produksi, tanggal kadaluarsa, perhitungan masa efektif pakai, penentuan nilai jual efektif yang berubah setiap periode waktu.

3. Penelitian yang dilakukan oleh Ridwan Aripin Nasution (2011) penelitian ini berjudul "Aplikasi Sistem Inventory Berbasis Dekstop Menggunakan JSE Pada CV. Sumber Logam Teknik Tangerang". Pada penelitian ini penulis hanya membahas mengenai persediaan barang yang dibatasi hanya pada proses prosedur input barang, input supplier, pembelian barang, faktur barang, retur barang, dan laporan kepada pimpinan. Analisis dilakukan dengan cara observasi terhadap sistem yang berjalan, kebutuhan informasi sistem, dan desain menggunakan UML dan pembuatan program menggunakan netbeans dan DBMS MySQL. Keunggulan sistem aplikasi ini terletak pada proses input dan output, dimana untuk proses input pada form penerimaan terdapat menu pilihan satuan barang yang dapat dipilih salah satunya. Untuk outputnya dalam bentuk rincian laporan perbulan, dimana manajer bisa memilih bulan yang ingin dicetak pada menu cetak laporan.

4. Penelitian yang dilakukan oleh Makrothymia Hia (2013) penelitian ini berjudul "Perancangan Sistem Informasi Persediaan Barang pada PT. Gema Sarana Media". Pada penelitian ini penulis membahas tentang perancangan sistem informasi persediaan barang untuk mempermudah bagian gudang, yaitu meliputi proses data barang masuk, barang keluar, data supplier, data customer, dan pembuatan laporan persediaan barang pada PT. Gema Sarana Media. Adapun metodologi yang dipergunakan lalu digambarkan dalam bentuk Use Case dengan menggunakan UML versi 6.4. Rancangan sistem ini memberikan banyak kemudahan, yaitu memudahkan proses pembuatan laporan, memudahkan dalam pencarian data, dan memudahkan staf bagian gudang untuk mengetahui stok barang yang masuk dan barang yang keluar.

5. Penelitian yang dilakukan oleh $\mathrm{M}$. Syah Reza (2012) penelitian ini berjudul "Aplikasi Persediaan Barang Pada CV. Kiki Optical Berbasis Website". Pada penelitian ini penulis membuat suatu program berbasis website yang bisa digunakan untuk mengontrol stok minimal barang dan menampilkan informasi barang yang ada di gudang. CV. Kiki Optical bergerak dibidang optik kacamata. Aplikasi persediaan barang berbasis website dibuat dengan menggunakan bahasa pemrograman PHP dan MySQL untuk mengelola databasenya dan mampu merekam seluruh data persediaan barang. Metode penelitian yang digunakan dalam penelitian di CV. Kiki Optical ini adalah metode deskriptif dengan jenis penelitian studi kasus. Teknik pengumpulan data menggunakan metode wawancara dan kuisioner. Dengan adanya sistem berbasis $w e b$, pengecekan barang lebih cepat, dapat memudahkan admin membuat laporan bulanan yang lebih cepat, tepat, dan akurat. Tetapi sistem yang diusulkan ini baru sebatas dekstop aplikasi berbasis web dan belum berbasis online. 
6. Penelitian yang dilakukan oleh Nenden Sri Jayantina (2010) penelitian ini berjudul "Perancangan Aplikasi Inventaris Alat Dan Bahan di Laboratorium PPPPTK IPA Bandung". pada penelitianini penulis membuat suatu program berbasis website yang bisa digunakan untuk mengontol barang alat dan bahan dan menampilkan informasi barang yang ada di Laboratorium PPPPTK IPA Bandung. Aplikasi Inventaris alat dan bahan berbasis website dibuat dengan menggunakan bahasa pemrograman PHP dan MySql untuk mengelola databasenya dan mampun merekan seluruh data Aplikasi Inventaris alat dan bahan. Metode penelitian yang di gunakan dalam penelitian di Laboratorium PPPTK IPA Bandung adalah metode deskriptif dengan jenis penelitian studi kasus. Teknik Teknik pengumpulan data menggunakan metode wawancara dan kuisioner. Dengan adanya sistem berbasis web, pengecekan barang lebih cepat, dapat memudahkan admin membuat laporan bulanan yang lebih cepat, tepat, dan akurat. Tetapi sistem yang diusulkan ini baru sebatas dekstop aplikasi berbasis web dan belum berbasis online.

7. Penelitian yang dilakukan oleh Ninik Tri Kartini (2007) penelitian ini berjudul "Sistem Inventory Labkom SMKN 1 Karang Anyar". pada penelitianini penulis membuat suatu program berbasis database sistem Microsoft Access. Sistem Inventory dapat diartikan sebagai suatu aplikasi yang meliputi input, proses dan output dimana data yang dioleh merupakan data dari seluruh perlengkapan (data barang) yang dimiliki oleh Inventory Labkom SMKN 1 Karang Anyar. Labkom SMKN 1 Karang Anyar berbasis database sistem Microsoft Access dibuat dengan menggunakan bahasa pemrograman Pascal atau Delphi untuk mengelola databasenya dan mampun merekan seluruh data database sistem Microsoft Access. Metode penelitian yang di gunakan dalam penelitian di Labkom SMKN 1 Karang Anyar adalah metode deskriptif dengan jenis penelitian studi kasus. Teknik Teknik pengumpulan data menggunakan metode wawancara. Dengan adanya sistem berbasis sistem Microsoft Acces, pengecekanLabkom SMKN 1 Karang Anyar lebih cepat, dapat memudahkan admin membuat laporan bulanan yang lebih cepat, tepat, dan akurat. Tetapi sistem yang diusulkan ini baru sebatas dekstop aplikasi berbasis sistem Microsoft Acces dan belum berbasis Local Area.

8. Penelitian yang dilakukan oleh Salamah Permadyanti Putri (2013) penelitian ini berjudul "Sistem Informasi Inventory Laboratorium Bersasis Web Pada SMA Negeri 4 Yogyakarta". pada penelitianini penulis membuat suatu program berbasis Web. Sistem Inventory dapat diartikan sebagai suatu aplikasi yang meliputi input, Sistem informasi inventaris laboratorium sangat diperlukan karena dapat memberikan kemudahan dalam melakukan proses inventarisasi peralatan yang ada pada laboratorium baik dari segi pengarsipan, perawatan, peminjaman, maupun alat keluar. yang dimiliki oleh Inventory Laboratorium Bersasis $\mathrm{Web}$ Pada SMA Negeri 4 Yogyakarta berbasis Web. dibuat dengan menggunakan bahasa MySql dan XAMPP untuk mengelola databasenya dan mampun merekan seluruh data berbasis Web. Metode penelitian yang di gunakan dalam penelitian di Inventory Laboratorium Bersasis Web Pada SMA Negeri 4 Yogyakarta adalah metode deskriptif dengan jenis penelitian studi kasus. Teknik Teknik pengumpulan data menggunakan metode wawancara. Dengan adanya sistem berbasis Web, pengecekan 
Inventory Laboratorium Bersasis $\mathrm{Web}$ Pada SMA Negeri 4 Yogyakarta lebih cepat, dapat memudahkan admin membuat laporan bulanan yang lebih cepat, tepat, dan akurat. Tetapi sistem yang diusulkan ini baru sebatas dekstop aplikasi berbasis sistem web dan belum berbasis Local Area.

\section{PEMECAHAN MASALAH}

Untuk mengatasi berbagai masalah diatas, maka diperlukan proses yang cepat dan efisien dalam mengakses seluruh data yang banyak dan tidak teratur pada media penyimpanan yang berupa sebuah sistem, terlebih untuk suatu sistem informasi yang akurat. Dalam mencapai tujuan menerapkan sistem inventory Lab. Digital dengan menggunakan metode CSF pada Perguruan Tinggi Raharja, maka diperlukan metode analaisa yang nyata.

Pada pemecahanan masalah menggunakan metode analaisa CSF ini akan dielaborasikan visi dan misi menjadi tujuan bisnis bagi Perguruan Tinggi Raharja yang kemudian akan diaplikasikan menggunakan CSF analisis untuk menemukan kebutuhan Lab. Digital pada Perguruan Tinggi Raharja dari organisasi. Langkah-langkah elaborasi tersebut dapat dijelaskan pada gambar di bawah ini, yaitu

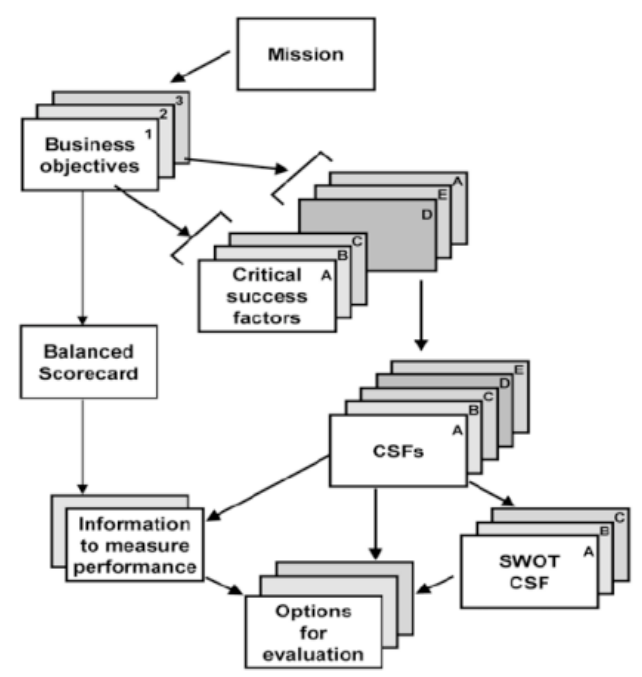

\section{Gambar 3. Critical Succes Factors}

Berdasarkan hasil observasi pada Perguruan Tinggi Raharja, didapatkan pernyataan visi misi dari Perguruan Tinggi Raharja. Tujuan utama dari Perguruan Tinggi Raharja tertuang dalam sistem pengolahan informasi inventory, pengembangan penelitian dan kegiatan, memaksimalkan penerapan program penelitian, dan keakuratan data yang dapat dimonitoring sehingga menghasilkan suatu laporan yang dapat memudahkan pimpinan dalam mengambil suatu keputusan, dapat dilihat pada tabel dibawah ini, yaitu:

Tabel 1. Tujuan utama dan CSF Sistem

Informasi Pada Perguruan Tinggi Raharja
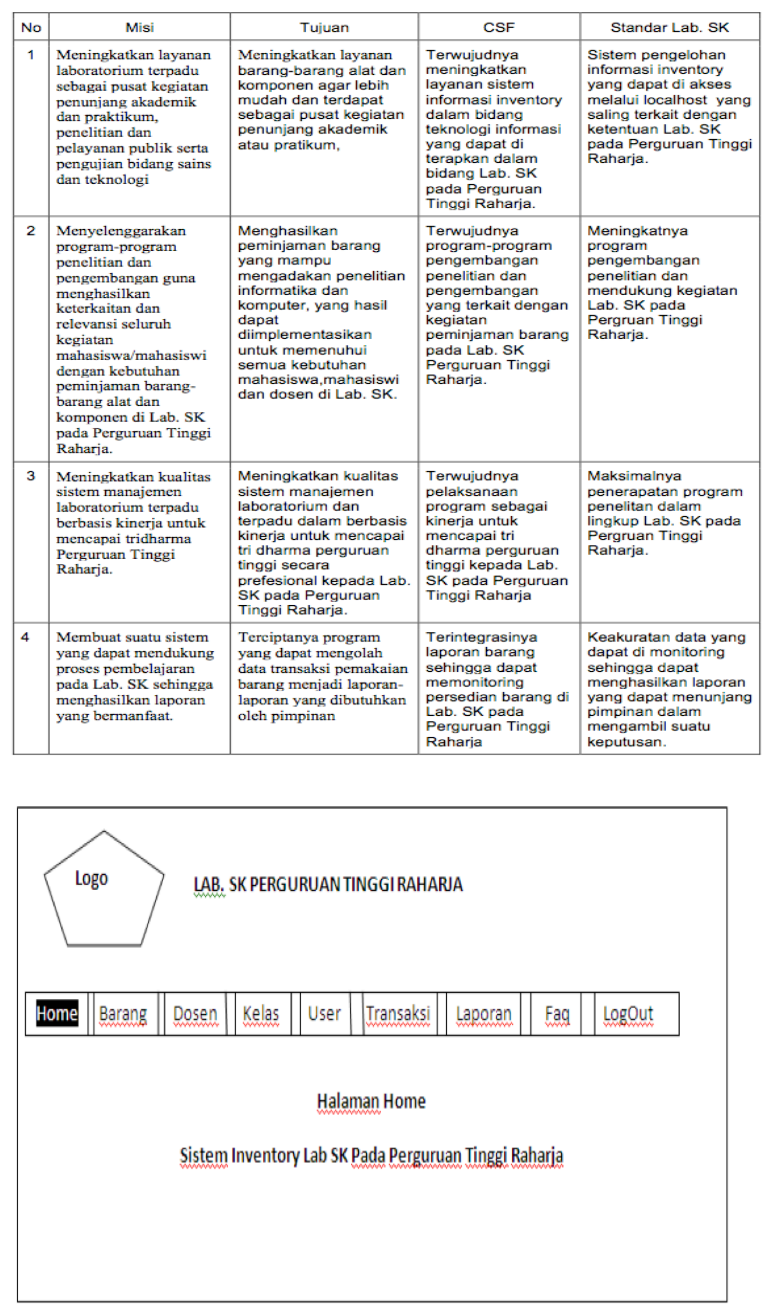

Gambar 4. Prototype Page Sistem Inventory Lab. Digital 
Flowchart program dalam pemecahan masalah merupakan keterangan yang lebih rinci tentang bagaimana setiap langkah program atau prosedur sesungguhnya akan dilaksanakan. Flowchart ini menunjukan setiap langkah program atau prosedur dalam urutan yang tepat saat terjadi. Berikut Flowchart program Sistem Inventory Lab. Digital Pada Perguruan Tinggi Raharja, yaitu sebagai berikut :

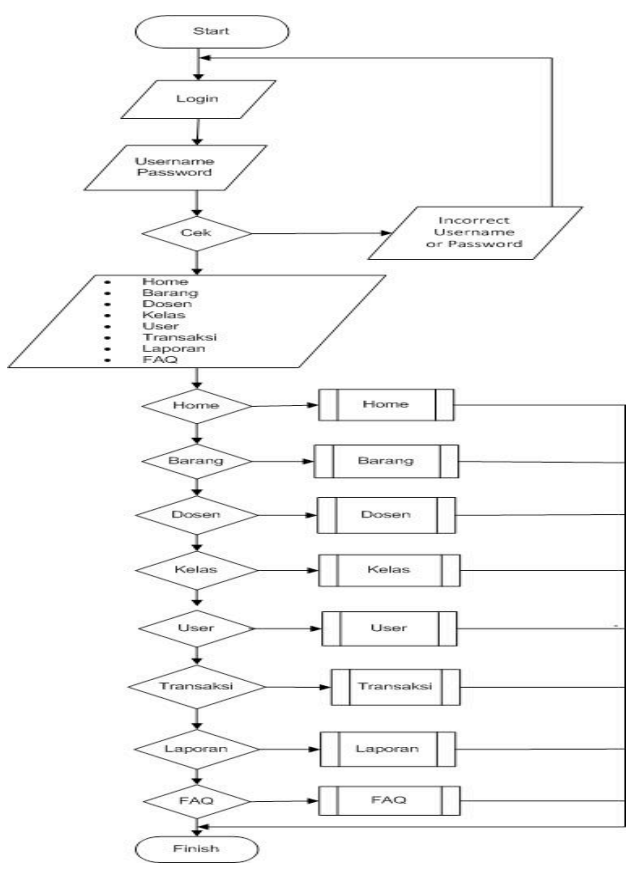

Gambar 5. Flowchart Program Inventory Lab. Digital

Dapat dijelaskan gambar 4 flowchart program inventory lab. digital Pada Perguruan Tinggi Raharja diatas pada saat ini terdiri dari:

1. 2 (dua) simbol terminal, yang berperan sebagai "start" dan "finish" pada aliran proses flowchart program pada sistem inventory lab. digital.

2. 3 (tiga) simbol data, yang menyatakan proses input atau output tanpa tergantung jenis peralatannya, yaitu: "login", kemudian untuk login admin harus memasukan "username password", dan jika salah sistem akan memberikan data yang bertuliskan "Incorrect username or password".
3. 9 (sembilan) simbol decision, sebagai simbol untuk menunjukan sebuah langkah pengambilan suatu keputusan untuk mengecek validasi kebenaran username dan password, jika "ya" akan bisa masuk ke home sistem dan jika "tidak" akan kembali ke login terlebih dahulu. Flowchart program pada sistem inventory lab. digital terdiri dari 9 (sembilan) simbol decision, yaitu : cek, home, barang, dosen, kelas, user, transaksi, laporan, dan FAQ.

4. 8 (delapan) simbol subprocess sebagai simbol yang menunjukan bahwa didalam langkah yang dimaksud terdapat flowchart lain yang menggambarkan langkah secara rinci yang terdiri dari 8 (delapan) macammacam menu, yaitu: home, barang, dosen, kelas, user, transaksi, laporan, dan FAQ.

\section{IMPLEMENTASI}

Tampilan sistem inventory lab. digital memiliki berbagai macam fitur yang dapat digunakan oleh admin, asslab, kajur, dan pimpinan yang terdiri dari:

\section{A. Tampilan Menu Data Barang}

Pada tampilan menu data barang ini memberikan informasi data barang secara lengkap, yaitu ID barang, nama barang, kategori barang, foto barang, stok barang, kondisi barang, dan sampai fasilitas untuk input data barang terdapat didalam menu data barang pada Lab. Digital Perguruan Tinggi Raharja yang dapat memberikan informasi lengkap mengenai persediaan barang didalamnya. 


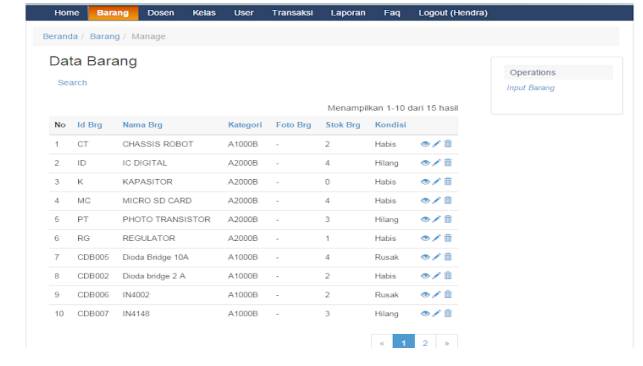

Gambar 6. Tampilan Menu Data Barang

\section{B. Tampilan Menu Data Dosen}

Tampilan ini menunjukan data dosen pengampuh perkuliahan yang melibatkan Lab. Digital dalam proses pembelajarannya sehingga jika ada dosen yang ingin meminjam barang yang ada di Lab. Digital dapat terhimpun dengan rapih data pemakaiannya.

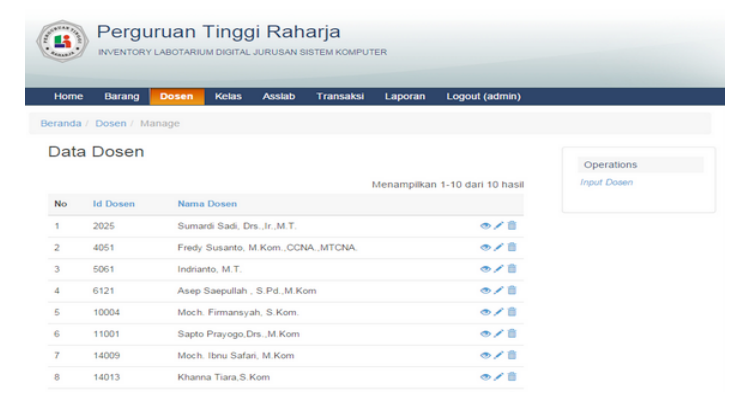

Gambar 7. Tampilan Menu Data Dosen

C. Tampilan Menu Data Kelas

Pada tampilan ini tidak hanya data barang yang terhimpun dengan rapih tetapi data kelas juga dapat dilihat, sehingga dapat dipastikan kelas yang menggunakan barang pada Lab. Digital dapat terlihat dengan jelas sehingga memudahkan untuk pimpinan dalam mengambil suatu keputusan dengan laporan yang ada didukung dengan data yang lengkap.

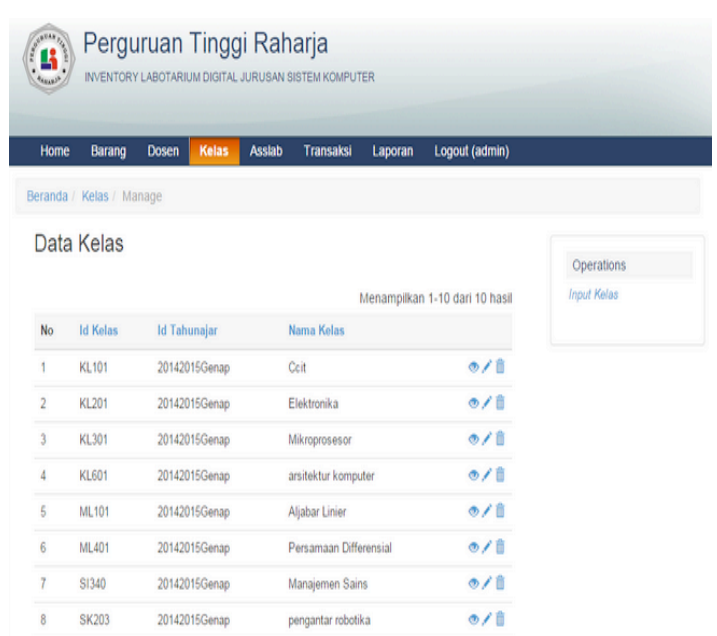

Gambar 8. Tampilan Menu Data
Kelas

\section{Kelebihan Sistem Inventory Lab. Digital}

Dengan adanya penggunaan metode analisa CSF yang dikehendaki oleh responden memiliki kegunaannya didalam menganalisa sistem inventory Lab. Digital yang ada saat ini dapat memaksimalkan peran dari Lab. Digital itu sendiri dalam persedian data barang yang dapat termonitoring dengan baik sehingga memudahkan kajur dalam membuat laporan untuk diberikan kepada pimpinan sehingga memudahkan pimpinan dalam mengambil suatu keputusan. Stok yang terdapat didalam Lab. Digital dapat dimaksimal proses pembelajaran atau praktikum yang didukung dengan adanya alat yang memadai dan tersimpan datanya dengan rapih. Setiap transaksi yang dilakukan yaitu pemakaian dan pengembalian barang dapat tersusun dengan rapih sehingga laporan dapat terhimpun seperti laporan stok data barang dan laporan pemakaian. Ini berguna bagi Perguruan Tinggi Raharja dalam memonitoring persediaan barang didalam Lab. Digital.

\section{Kekurangan Sistem Inventory Lab. Digital}

Sistem inventory Lab. Digital ini belum mempunyai "warning system". Warning 
system yang dimaksud adalah sebuah peringatan yang muncul disaat beberapa hal yang sudah ditentukan masa waktu atau masa persediaannya sudah mendekati minimal persediaan yang sudah ditentukan. Warning system yang dibutuhkan saat ini pada sistem yang ada yaitu peringatan untuk data barang, jika stok yang ada sudah mendekati minimal barang yang sudah ditentukan maka sistem akan menampilan peringatan berupa pesan kepada admin dan asslab sehingga dapat memudahkan untuk admin dan asslab dalam membuat sebuah laporan dan tetap memonitoring persediaan barang dengan baik sehingga perkuliahan dan praktikum yang dilaksanakan dapat didukung dengan alat yang memadai. Tidak hanya dalam memonitoring persediaan barang didalam Lab. Digital tetapi juga memudahkan pimpinan dalam mengambil suatu keputusan untuk memenuhi kebutuhan persediaan barang didalam Lab. Digital dapat tersedia dengan baik.

\section{KESIMPULAN}

Dengan demikian dapat disimpulkan, bahwa dengan adanya sistem inventory pada Lab. Digital Perguruan Tinggi Raharja, diharapkan sistem dapat memberikan informasi sesuai dengan kebutuhan mahasiswa dan dosen dalam belajar mengajar yang telah dianalisa dengan menggunakan metode CSF (Critical Success Factor) yang dapat meningkatkan standar Lab. Digital dalam mengelola persediaan barang yang dapat diakses secara lokal oleh bagian terkait, serta meningkatkan program pengembangan penelitian dan mendukung proses belajar mengajar untuk perkuliahan dan praktikum dapat berjalan dengan baik, memaksimalkan penerapan program penelitian dalam lingkup kreatifitas dan pemahaman, dan juga keakuratan data dapat termonitoring sehingga dapat menghasilkan laporan yang dapat membantu pimpinan dalam mengambil suatu keputusan. Dengan adanya sistem inventory Lab. Digital ini, diharapkan pengelolaan data barang yang ada menjadi lebih mudah karena penggunaan database yang tergintegerasi dengan baik dan diproses secara terkomputerisasiyang dapat memungkinkan hasil pengolahan data akan lebih cepat, tepat, akurat sehingga persediaan barang didalam Lab. Digital dapat termonitoring dengan baik.

\section{DAFTAR PUSTAKA}

[1] Gunardi, S. Dedi Sulistyo, Suryana. Taryana (2012). "Usulan Peta Strategi Teknologi Informasi Menggunakan Pendekatan Analisis Critical Succes Factors Dan IT Balanced Scorecard". Bandung: UNIKOM

[2] Hia, Makrothymia, (2013) "Perancangan Sistem Informasi Persediaan Barang pada PT. Gema Sarana Media".

[3] Jayantina. Nenden Sri (2010). "Perancangan Aplikasi Inventaris Alat Dan Bahan di Laboratorium PPPPTK IPA Bandung".

[4] Junaidi, Tiara. Khanna, Yuliastrie. Nenden Dewi. Sistem Pakar Monitoring Inventory Control Untuk Menghitung Harga Jual Efektif Dalam Meningkatkan Keuntungan. Yogyakarta: Universitas Ahmad Dahlan.

[5] Kartini. Ninik Tri (2007) "Sistem Inventory Labkom SMKN 1 Karang Anyar".

[6] Nasution. Aripin Ridwan (2011) "Aplikasi Sistem Inventory Berbasis Dekstop Menggunakan JSE Pada CV. Sumber Logam Teknik Tangerang". 
[7] Mustakini. Jogiyanto Hartono. 2009. SistemTeknologi Informasi. Yogyakarta: Andi.

[8] Nugroho, Bondan Dwi, dan Imam Azhari. Sistem Informasi Inventori FADEGORETAS!! TM Berbasis Barcode. Yogyakarta: Universitas Ahmad Dahlan. Vol. 1, No. 2, September 2011.

[9] Praptiningsih, Yulia Eka. 2012. Aplikasi Penyewaan Ruangan PT. Simaeru Indonesia Raya Dengan Visual Basic 6.0. Depok: Universitas Gunadarma, UG Jurnal Vol. 6 No. 01, 2012.

[10]Putri. Salamah Permadyanti (2013). "Sistem Informasi Inventory Laboratorium Bersasis Web Pada SMA Negeri 4 Yogyakarta".

[11] Witarto, Rockart dan Bullen. 1981. Memahami Sistem Informasi. Bandung: Informatika.

[12]Widyaningsih, Pipin. 2014. Perencanaan Strategis Sistem Informasi Pada Institusi Pendidikan Menggunakan Analaisa CSF (Studi Kasus : STMIK Duta Bangsa Surakarta).

[13]Reza, M Syah (2012). "Aplikasi Persediaan Barang Pada CV. Kiki Optical Berbasis Website". Tangerang: Perguruan Tinggi Raharja.

[14] Salangka. Ester. 2013. Penerapan Akuntansi Persediaan UntukPerencanaan Dan Pengendalian LPG Pada PT. Emigas Sejahtera Minahasa. Manado: Universitas Sam Ratulangi.

[15] Sutabri. Tata. 2012. Konsep Sistem Informasi. Yogyakarta: Andi.

[16] Tamodia. Widya. 2013. Evaluasi Penerapan Sistem Pengendalian
Intern Untuk Persediaan Barang Dagangan Pada PT. Laris Manis Utama Cabang Manado. Manado: Universitas Sam Ratulangi. 